\title{
JOYCE FINNEGANS WAKE
}

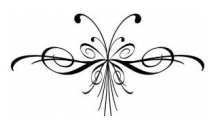

PAULO LEMINSKI

Nicolau foi uma publicação cultural lançada em julho de 1987, em Curitiba, sob o patrocínio do Governo do Estado do Paraná e coordenação de Wilson Bueno. Apresentava 28 páginas, contava com uma tiragem que ultrapassava os 150 mil exemplares, e circulava mensal e gratuitamente como anexo a jornais paranaenses, ou era enviado por correio a outras localidades.

Reproduzimos aqui o texto e a tradução de Paulo Leminski de excerto do Finnegans Wake tal como publicados no Nicolau de 12 de junho de 1988, com o acréscimo das passagens ausentes às passagens do original então publicadas e adequando o conteúdo ao padrão gráfico da Scientia Traductionis. Agradecemos a Lenita Rimoli Esteves e a Maurício Mendonça Cardozo por recuperar o texto de Leminski.

Gustavo Althoff

Dezembro de 2010

O Finnegans Wake, de James Joyce (1882 - 1941), é como um 'universo textual' dinâmico, em expansão, com miríadas de astros, galáxias, nebulosas, buracos-negros, quasares. Universo-ilha de estrutura circular, com virtuais e infinitos inventos, combinações, sentidos. Um quebra-cabeça cósmico.

Aqui, Paulo Leminski apresenta sua versão de um fragmento dessa obra quase-intraduzível do genial escritor irlandês: o Wake desperto no riocorrente da língua portuguesa.

Paulo Leminski, autor, entre outras obras, de Catatau (1975), Não fosse isso... (Zap, 1980), Caprichos e Relaxos (Brasiliense, 1983/Círculo do Livro, 1987), Agora é que são elas (Brasiliense. 1985), Trotski. a Paixão segundo a Revolução (Brasiliense, 1985), Anseios Crípticos (Criar Edições, 
1986), Distraídos venceremos (Brasiliense, 1987). Sua atividade de tradutor compreende a recriação para o português de Petrônio, Beckett, Mishima, John Lennon, Jarry, Ferlinghetti, Fante e Joyce.

Nicolau

Junho de 1988

quele irlandês era o maior escritor que o mundo já tinha
visto. O Ulysses deixou todo mundo em pânico, de Pound a
Jung, dos juízes aos críticos literários. Mas havia um alívio.

Os especialistas pensavam: só daqui a mil anos aparecerá uma obra tão radical, tão nova, tão poderosa quanto esta.

Mal sabiam eles que o próprio autor do Ulysses já incubava aquela obra que superaria Ulysses ("o romance para acabar com todos os romances") e da qual Ulysses não seria mais que um preâmbulo: Finnegans Wake.

Finnegans Wake (O Despertar de Finnegans) é a mais alta realização literária deste século - talvez de todos os séculos.

Falando dele, Joyce mesmo: "Um dia, entenderão que eu fui o maior engenheiro que jamais houve"

Escrito de 1922 (Semana de Arte Moderna, no Brasil) a 1939 (começo da $2^{\text {a }}$ Guerra Mundial), $O$ Despertar de Finnegans é um volume de 628 páginas, de riqueza inesgotável.

Para dar uma idéia: Finnegans Wake é um sonho colossal, tendo por personagem a Humanidade. Esse sonho é a História, essa História da qual Joyce dizia que era "um pesadelo do qual queria acordar".

Esse personagem multiplica-se, através de um fantástico caleidoscópio, em dezenas de entidades prototípicas.

Esse fantástico caleidoscópio era a mente desse irlandês que sofria da vista (por causa de excesso de leitura e de escrita) e que estava constantemente de cara cheia.

As entidades prototípicas são, principalmente, o princípio masculino (yang, encarnado no indivíduo Humphrey Chimpden Earwicker) e o princípio feminino (ying, encarnado em Anna Livia Plurabelle).

Esses princípios podem metamorfosear-se em muitos outros (o princípio masculino pode ser o Tristão, de Tristão e Isolda, por exemplo).

Miticamente, o princípio masculino é simbolizado por elevações, montanhas, castelos (símbolos fálicos) e o princípio feminino pela água (o 
nome Livia de Anna Livia ecoa no nome do rio Liffey, que banha Dublin, a terra natal de Joyce).

O princípio masculino é obviamente Adão e o feminino Eva.

Eles têm dois filhos. Shem e Shaun (Caim e Abel), um homem de ação e o outro homem de reflexão, escritor (o próprio Joyce, é claro).

O trecho que traduzimos é uma "carta" de Shem the Penman (o homem pena, o escriba).

Sobre esse tecido aparentemente simples, superpõe-se uma série fantástica de personagens e eventos, num processo de palimpsesto (manuscritos super-impostos).

Finnegans é um gigante da lenda irlandesa, que despertará quando a Irlanda precisar dele. É ainda um pedreiro que cai de uma escada, morre e ressuscita no funeral, quando os amigos derramam uísque na sua cara, dentro do caixão.

É mais uma encarnação do princípio masculino. O Finnegans Wake é uma imagem da ascensão e queda das civilizações, queda aí sendo também a queda de Adão, que introduz o homem paradisíaco na História.

Para montar essa máquina, Joyce, escrevendo em inglês, lança mão de muitos idiomas (Joyce era professor de línguas das escolas Berlitz) e de todos os recursos literários possíveis. O Finnegans Wake tem estrutura circular. Sua última palavra é o artigo the, que remete à palavra inicial riverrun, fechando o circuito.

No interior desse universo textual fechado, tem lugar a mais fantástica aventura literária jamais tentada.

\section{Joyce e o Brasil}

A despeito dos protestos do próprio, a escritura do maior prosador brasileiro, Guimarães Rosa, é devedora da experiência joyciana.

Joyce foi proposto pela Poesia Concreta, nos idos de 50, como um dos autores que, em nível internacional, configuravam uma nova prática do texto. Os outros: Mallarmé e Pound.

Alguns dos recursos utilizados por Joyce passaram a fazer parte do repertório da poesia brasileira de invenção, entre eles, o port-manteau, a palavra-montagem (que Lewis Carroll inventou e que chamou a atenção de Eisenstein, o genial cineasta russo).

Augusto de Campos e Haroldo de Campos, poetas concretos, foram os primeiros a traduzir trechos do Wake para o português, tarefa considerada impossível por muitos. 
Em 1962 saíram trechos no volume Panaroma do Finnegans Wake, pelo Conselho Estadual de Cultura de São Paulo.

Com novos trechos traduzidos, saiu em 1971 o Panaroma da Editora Perspectiva.

\section{A Presente Tradução}

O trecho do Wake aqui apresentado, pela primeira vez traduzido ao português, é a abertura da carta de Shem the Penman, onde se revelam algumas das concepções mais importantes de Joyce (que é Shem, em hebraico "nome" e também um meio de dizer "Jeová", fato que parece não ter sido notado até agora) sobre a escrita, sobre a natureza do texto e sobre o próprio Wake.

$\mathrm{O}$ original da tradução (que tomou muitas horas) corresponde à página 104 e seguintes da edição de 1964 (Faber \& Faber, Londres).

Traduzir oFinnegans Wake, como sempre, é uma aventura constante.

Impossibilidades.

Barreiras intransponíveis.

Desafios.

Não se pode traduzir só significados.

Tem-se que trazudir também O SIGNIFICANTE.

Daí, a dialética tortura-delícia: um exercício de sadomasoquismo.

Traduzir o Wake, ascese e libertinagem.

Os resultados - sempre uma tentativa.

Um quase.

Sempre - um mais ou menos. 
FINNEGANS WAKE

\author{
JAMES JOYCE
}

\section{FINNEGANS WAKE}

PAULO LEMINSKI
Episode 1: Part 5

In the name of Annah the Allmaziful, the Everliving, the Bringer of Plurabilities, haloed be her eve, her singtime sung, her rill be run, unhemmed as it is uneven!

Her untitled mamafesta memorialising the Mosthighest has gone by many names at disjointed times. Thus we hear of, The Augusta Angustissimost for Old Seabeastius' Salvation, Rockabill Booby in the Wave Trough, Here's to the Relicts of All Decencies, Anna Stessa's Rise to Notice, (...) Rebus de Hibernicis, The Crazier Letters, Groans of a Britoness, Peter Peopler Picked a Plot to Pitch his Poppolin, (...) Cock in the Pot for Father, (...) A New Cure for an Old Clap, (...) I Led the Life, (...) The Best in the West, By the Stream of Zemzem under Zigzag Hill, The Man That Made His Mother in the Marlborry Train, (...) Drink to Him, (...) I Ask You to Believe I was his Mistress, (...)What Jumbo made to Jalice and what Anisette to Him, (...) Look to the Lady, From the Rise

\section{Episódio 1: Parte 5}

Em norme de Annah ${ }^{1}$ Anipatente Sempresente, Linfia de Plurabilidades, ovacionado seja seu evo, seu somtempo soado, seu rio seja chão, desagual no seu desigual!

Seus desintitulados mamafestos memorializando o Maisaltíssimo têm passado por inúmeros nomes em desconjuntados tempos. Assim deu para ouvir acerca de $O$ Augusta Angustissimais para a Salvação de Salbestial, Aqui as Relíxias de Todas as Decências, Ascensão de Ana Stessa até a Notícia, Rebus de Hibernicis (Das Coisas da Irlanda), Cartas Curtas, Papai, o Pato está no Papo, Nova Cura para uma Velha Sinecura, Vivi a Vida, O Melhor na Mulher, Ao Longo do Rio Zemzem sob a Colina do Zigzag, O Homem que Faturou sua Mãe no Trem de Malborry, Beba a Ele, Peço que Creia que Eu era Amante Dele, Da Ascensão de Dudge Pupúblico à Queda de Postestilo, O que Jumbo fez a Jalice e Anisette a Ele, Manje a Madame, Dos Dois Modos de

\footnotetext{
${ }^{1}$ É Anna Livia Plurabelle, princípio feminino do Wake. A abertura é paródia das Suratas
} do Alcorão: "Em nome de Allah..." 
of the Dudge Pupublick to the Fall of the Potstille, Of the Two Ways of Opening the Mouth, (...) How to Pull a Good Horuscoup even when Oldsire is Dead to the World, (...) My Skin Appeals to Three Senses and My Curly Lips Demand Columbkisses; (...) Siegfield Follies and or a Gentlehomme's Faut Pas, (...) The Suspended Sentence, A Pretty Brick Story for Childsize Heroes, (...) Thonderbalt Captain Smeth and La Belle Sauvage Pocahonteuse, (...) The Last of the Fingallians, (...) Lumptytumtumpty had a Big Fall, (...) The Flash that Flies from Vuggy's Eyes has Set Me Hair On Fire, His is the House that Malt Made, Divine Views from Back to the Front (...) Seven Wives Awake Aweek, (...) From the Manorlord Hoved to the Misses O'Mollies and from the Dames to their Sames, (...) As Tree is Quick and Stone is White So ts My Washing Done by Night, (...) L.S.D., (..)

The proteiform graph itself is a polyhedron of scripture. There was a time when naif alphabetters would have written it down the tracing of a purely deliquescent recidivist, possibly ambidextrous, snubnosed probably and presenting a strangely profound rainbowl in his (or her) occiput. To the hardily curiosing entomophilust
Abrir a Boca, Como Levantar um Bom Horusgolpe Mesmo quando o Ansião está de Dados com o Dédalo, Minha Pele Atrai Três Sentidos e Meus Lábios Encaracolados Exigem Beijospombas, Siegfield Follies e/ou o Palso em Farso de um Gentilembra, A Sentença Suspensa, Uma Bela História de Tijolos para Heróis de Meias Tijelas, Capitão Silva Arrepiolâmpago e a Bela Selvagem Pocahontária, O Último dos Fingalianos, Lumptytumtumpty Levou um Bruta Tombo, O Flash que Flui dos Olhos de Vuggy Tocou Fogo nos Cabelos Meus, Coisa é a Casa que Felix Fez, Vistas Divinas no Fronte Ocidental, Matou Maria e Morou Mais que Eu em Moscou, Caminho mais Curto para uma Semana com Selma Selmanoff, L. S. D., Sete Esposas Acordando de Acordo, Como a Árvore é Rápida e a Pedra é Branca Tal Minha Lavanderia de Noite (...) ${ }^{2}$

A grafia proteiforme é por si mesma uma polihidra de escriptura. Houve um tempo quando noivos alfabertos teriam escrito o trançado de um recidivista em puro estado delinquescente, possivelmente ambiedextro, de nariz arrebitado provavelmente e apresentando um marco-íris estranhamente profundo sobre o cocuruto.

\footnotetext{
${ }^{2}$ Segue a lista de títulos fantásticos de livros absurdos, a biblioteca desse escriba incrível. Shem: o bloco todo transmite uma sensação de non-sense, crítica da cultura letrada.
} 
then it has shown a very sexmosaic of nymphosis in which the eternal chimerahunter Oriolopos, now frond of sugars, then lief of saults, the sensory crowd in his belly coupled with an eye for the goods trooth bewilderblissed by their night effluvia with guns like drums and fondlers like forceps persequestellates his vanessas from flore to flore. Somehows this sounds like the purest kidooleyoon wherein our madernacerution of lour lore is rich.

All's so herou from us him in a kitchernott darkness, by hasard and worn rolls arered, we must grope on till Zerogh hour like pou owl giaours as we are would we salve aught of moments for our aysore today. Amousin though not but. Closer inspection of the bordereau would reveal a multiplicity of personalities inflicted on the documents or document and some prevision of virtual crime or crimes might be made by anyone unwary enough before any suitable occasion for it or them had so far managed to happen along. In fact, under the closed eyes of the inspectors the traits featuring the chiaroscuro coalesce, their contrarieties eliminated, in one stable somebody similarly as by the providential warring of
Para o entomofilúbrico dificilmente curioso, então mostrou um verdadeiro sexomosaico de ninfose no qual o eterno caça-quimeras Oriolops $^{3}$, ora galho de açúcar, logo folha de sais, a multidão sensória em sua barriga locupletada com um olho para os profeitos benfeitiçada por seus noturnais eflúvios com baterias em batucada e carinhos como fórceps esquadradinhando suas vanessas de saolho a soalho. De vezes em quandos, isto soa como o mais puro meninídolo ondedentro nossa madernacerução de norsa saga é rica.

Tudo é tão longe herói de nós aqui numa escuridão culinária por acaso e vermelhos são os volumes gastos, nós temos que tatear até que a hierohora como mil negros dias como somos havíamos de salvar tivéssemos momentos para nosso outrora hoje. Redivertido embora não mas. Inspeção mais atenta do bordereau (aqualimite) revelaria uma multiplicidade de personalidades inflingida aos documentos e alguma previsão de crime virtual ou crimes poderia ser feita por qualquer um despreocupado bastante perante qualquer ocasião propícia para isso ou lhes tem até aqui sucedido de acontecer em todo o longo do percurso. De fato, sob os olhos fechados dos inspetores, os traços representando

\footnotetext{
${ }^{3}$ Horapolos, autor de uma obra com a'falsa' interpretação dos hieroglifos egípcios?
} 
heartshaker with housebreaker and of dramdrinker against freethinker our social something bowls along bumpily, experiencing a jolting series of prearranged disappointments, down the long lane of (it's as semper as oxhousehumper! Generations, more generations and still more generations.

Say, baroun lousadoor, who in hallhagal wrote the durn thing anyhow? Erect, beseated, mountback, against a partywall, below freezigrade, by the use of quill or style, with turbid or pellucid mind, accompanied or the reverse by mastication, interrupted by visit of seer to scribe or of scribe to site, atwixt two showers or atosst of a trike, rained upon or blown around, by a rightdown regular racer from the soil or by a too pained whittlewit laden with the loot of learning?

Now, patience; and remember patience is the great thing, and above all things else we must avoid anything like being or becoming out of patience. (...) chiaroscuro, concrescem, suas contradições eliminadas, num estábulo alguém similarmente como por providencial alerta de arrasa-corações com quebra-casas e bebedor-de-doses contra livrepensador nosso social qualquer negócio prossegue aos pulos, experimentando uma trepidante série de desapontamentos préarranjados, abaixo dos longos desfiladeiros (é pura exemplesmente como orcovadoboidecasa) de gerações, mais gerações e mais gerações ainda.

Diga, barbarão assassignalado, por que diabodiacho alguém escreveu esse troço afinal? Ereto, estabelecido, montado, abaixo de zerogrado, por uso de quilha ou estilo, com mente opaca ou transparente, acompanhada ou o contrário por mastigação, interrompida por visita de vidente ao escriba ou de escriba ao sítio, entre dois chuveiros ou no meio de um truque, chovido em cima ou ventado em volta, por um corredor regular junto ao solo ou por a um fardo muito pesado de aprendizado muito?

Agora, paciência; e lembrem que pasciência é a grande coisa e sobre qualquer outra coisa devemos evitar qualquer coisa como perder a paciência. (...)

Fonte: "Joyce Finnegans Wake" foi publicado em 12 de junho de 1988 em Nicolau 